\title{
Using Proverbs as a Lead-in Activity in Teaching English as a Foreign Language
}

\author{
Adnan Zaid \\ Universitas Teknologi Yogyakarta
}

\begin{abstract}
Teachers often find it difficult to keep their students' interest high in learning English. They have to do their best to attract the students' attention to the subject so that the students may have a feeling of pleasure while learning, and they are enhanced to learn more at the same time. Using English proverbs can serve as an alternative lead-in activity to start new lessons to keep the students interested in the lesson from the beginning. As the English proverb says that "Well begun is half done", teaching can be successful when the students are interested in the lesson from the start. Having an effective lead-in activity plays an important role for this purpose. Keeping the students' interest high is paramount for interest will drive students to explore more experience in the process of learning.

This paper will explore on how teachers can make use of proverbs to keep the students interested in learning English. Basically, proverbs reflect human experience across cultures and languages, which contain folk wisdom tested throughout the time. In relation to language teaching, they can be used to teach, among others, speaking, writing, grammar, vocabulary, culture, and values. Teachers can invite the students to make some comparison between English proverbs and local proverbs to start with. Looking for similarities and differences in proverbs from two different cultures may trigger students' curiosity to learn further. Introducing a foreign culture and values can be carried out through the use of proverbs. In line with the current issues of teaching character building, proverbs can be used in teaching character building as well.
\end{abstract}

Keywords: proverbs, lead-in activity, English teaching

\section{INTRODUCTION}

Due to the advancement of science and technology, the world is shrinking. Communication between people all over the world becomes so intensive that they need an international language by which they can share what they feel or when they run their business. English has become one important international language that is learned by people around the globe. Teaching and learning English becomes an important endeavour. Linguists and language teachers keep searching for the best method to teach English. However, teaching English as a foreign language is likely to be a story of failure. Many students give up learning the language for so many reasons before they master the language. To lessen the giving up, an English teacher must exert his/her efforts to make his/her teaching interesting and his/her students have fun while they are studying, and to lead their students to a great success in learning the target language. To do so he/she has to bring in various techniques to his/her classroom to avoid boredom in class. Something interesting must be presented right from the beginning of a class so that the students will be triggered to explore more, their concentration can be maintained, and that they can have fun at the same time.

To have a good start a teacher needs something to raise the students' motivation or to warm them up so that they will have a feeling pleasure during the learning process. A good lead-in activity is necessary to be done for this purpose. Reciting or using English proverbs can be an effective way to start a new lesson. When necesary, a teacher can compare English proverbs with Indonesian proverbs, for instance (Guse, 2011:177). Using L1 as a basis to learn L2 can be supportive (Ishihara, 2010: 3). For example, a teacher may ask his/her students to compare the English proverb "Make hay while the sun shines" with an Indonesian proverb "Sedia payung sebelum hujan" (Prepare an umbrella before it rains). By using the proverbs, a teacher can help her/his students learn English faster and get pleasant experience while the learning process is going on. A good start may guarantee happy and profitable time while the learning is taking place. An experienced teacher will know whether his/her class will be an interesting or not right from the beginning. If the class starts with merriful situation, the next step of teaching will be easier and the students will learn better. 


\section{Using Proverbs as a Lead-in Activity}

A lead-in activity will, to some degree, determine a successful class. That is why a teacher has to do his/her best to make his/her lead-in activity interesting, dramatic and vivid. English proverbs can be used as an alternative to have a lead-in activity.Webster defines a proverb as a short, traditional saying that expresses some obvious truth or similar experiences. Proverbs have been used as teaching tools for centuries to teach moral values and social skills. They may deal with mind, wisdom, experience, learning, and authority. They are indeed effective devices to communicate wisdom and knowledge about human nature and the world at large (Mieder, 2004:146). Proverbs contain a truth in few words that relate to everyday life having a universal value, and they can be remembered easily. Considering the good values of proverbs, a teacher may use proverbs to teach English as a foreign language as a lead-in activity prior to teaching language skills.It is a good way to consolidate the learning of vocabulary,grammar, sentence patterns, moral values, and the like.

\subsection{Grammar}

A teacher can use certain proverbs to start his/her grammar class prior to teaching the material in details. For example, a teacher who wants to teach gerund, he/she may use the following proverbs as a lead-in activity:

Seeing is believing.

Before criticizing a man, walk a mile in his schoes.

Lingting never strikes twice in the same place.

Missing the wood for the trees.

Thinking the worst always prepares you for the worst.

Winning is earning. Losing is learning.

In teaching imperative sentences, a teacher may use the following proverbs as a lead-in activity. It can be about positive and negative imperative sentences. Here are some examples of proverbs for this purpose:

\section{Positive:}

Fool me once, shame on you. Fool me twice, shame on me.

Give a man a fish and you feed him for a day, teach a man to fish and you feed him for a life time.

Look before you leap.

Make hay while the sun shines.

Never trouble trouble till trouble troubles you.

Negative:

Don't bite the hand that feeds you.

Don't burn your bridges before they're crossed.

Don't count your chickens before they're hatched.

Don't cry over spilt milk.

Don't judge a book by its cover.

In teaching article, $a$, an, or the, a teacher can show the use of articles used in proverbs and may ask the students to memorize the proverbs to internalize the pattern.

An apple a day keeps the doctor away.

A bird in the hand is worth two inthe bush.

$\boldsymbol{A}$ friend indeed is $\boldsymbol{a}$ friend indeed.

$\boldsymbol{A}$ pot of milk is ruined by a drop of poison.

An empty vessel makes the most noise. 


\subsection{Pronunciation}

Teaching pronunciation can be boring, but proverbs may offer some fun in this matter. In teaching pronunciation a teacher can use use proverbs bearing the some vowels or consonants which are difficult for the learners. Here are some examples of proverbs for this purpose:

\section{Vowels}

A friend in need is a friend indeed.

A good wife and health is a man's best wealth.

New lords, new laws.

Haste makes waste.

No joy without annoy.

\section{Consonants}

Practice makes perfect.

There is nothing which has been bitter before being ripe.

Birds of the same feather flock together.

Something is better than nothing.

A lazy youth, a lousy age.

Never trouble trouble till trouble troubles you.

\section{Rhyme}

The beauty of language can be something interesting to apply in making students interested in learning. Memorizing short proverbs with nice rhymes will stimulate the students to learn more and to train their organs of speech to practice the target language. Some examples of the following proverbs can be memorized by the students relatively easily:

No pain, no gain.

A friend in need is a friend indeed.

Haste makes waste.

There is no fool like an old fool.

Too many cooks spoil the broth.

\subsection{Speaking and Writing}

Thematic speaking ro writing can be started by introducing some proverbs related to the theme to be discussed. Repeating and memorizing the relevant proverbs will be useful for exercising the organs of speech. The next step is discussing the proverbs orally, or writing essays based on the chose proverbs. The theme can be varied in accordance with the students' interest, for example:

\section{Love}

Love is blind.

Loveless life is a living death.

Hatred is as blind as love.

Pity is akin to love.

\section{Friendship}

A friend in need is a friend indeed.

A friend to all is a friend to none.

Afriend's eye is a good mirror.

Friendship is like money, easier made than kept.

Friendship is love with understanding. 


\section{Money}

Time is money.

Money makes the world go around.

Money talks.

Money does not grow on trees.

In for a penny, in for a pound.

\subsection{Moral Values}

Since proverbs are rich in meaning, they can be used to teach moral values for the sake of teaching character building among the students and teaching English at the same time. Proverbs contain values of wisdom, discipline, fairness, friendship, preparedness, destiny, happiness, efforts, and so on. In teaching reading, for instance, a teacher may introduce some values which are found in the reading text. Here are some examples of proverbs bearing moral values:

Discipline : Time is money.

Health : An apple a day keeps the doctor away.

Optimism : Every cloud has a silver lining.

Preparedness: Make hay while the sun shines.

Friendship : A friend's eye is a good mirror.

Cautiousness : Don't judge a book by its cover.

\subsection{Culture}

Teaching a language cannot be separated from teaching the culture in that language. In fact, language is a part of one's culture. Consequently, when a teacher is teaching English, he/she will teach English culture at the same time. To introduce English culture, a teacher may use proverbs as a lead-in activity. Here are some examples of proverbs which can be used to introduce English culture.

Make hay while the sun shines.

Time is money.

An Englishman's home is his castle.

Every cloud has a silver lining.

Half loaf is better than none.

If in February there be no rain, it's neither good for hay nor grain.

\section{CONCLUding REMARKS}

A lead-in activity plays an important role in making a class successful. Interest is the first motives that enhance people to explore new experience. A teacher needs to make use of this phenomenon in teaching English. As the proverb says "A good beginning is a half battle", once the class is started with an enjoyable atmosphere, the next step will be fun accordingly. To have a lead-in activity, a teacher should bring in various techniques. One of the techniques that can be applied is the use of proverbs. The teacher needs to select proverbs which are relevant to the topic being discussed in class and which are in line with the students' level of learning.

Proverbs canserve as interesting lead-in activities because they are meaningful, and they contain some good values that can be practiced in daily life. In relation to character building, proverbs bear some educational values which can be used to build the students' character. English proverbs as the crystalization of collective wisdom are the essence of English. Based on thefeatures of English proverbs, a teacher can make use of the English as a lead-in activity. He/she can use them in teaching English skills, or the linguistic components of English. 


\section{REFERENCES}

Guse, J. 2011. Communicative Activities for EAP. Cambridge: Cambridge University Press.

Ishihara, N. \& Andrew D. Cohen. 2010. Teaching and Learning Pragmatics: Where Language and Culture Meet. Edinburgh Gate: Pearson Education Limited.

Lau, K.J., Peter Tokofsky, \& Stephen D. Winnick. 2004. What Goes Around Comes Around: The Circulation of Proverbs in Contemporary Life.Utah:Utah State University Press.

Mieder, W. 2004. Proverbs: A Handbook. Westport:Greenwood Press.

Samovar, L.A., Richard E. Porter, \& Edwin R. McDaniel. 2007. Communication Between Cultures. Wadsworth: Cengage Learning.

\section{AUTHOR's BIOGRAPHY}

Dr. H. Adnan Zaid, is an English language lecturer at Universitas Teknologi Yogyakarta. Currently he is the dean of faculty of letters at the University. He earned his Master Degree from Indiana University USA, and his Doctoral Degree from State University of Malang Indonesia. 